ノート

\title{
畜水産食品中の残留オキシテトラサイクリンの分析法
}

（平成 8 年 5 月 22 日受理）

$\begin{array}{lll}\text { 藤 田和弘*1 } & \text { 伊藤嘉奈子*1 } & \text { 荒木恵美子*2 } \\ \text { 丹野憲二*2 } & \text { 村山三徳*3 } & \text { 斎藤行生*3 }\end{array}$

\section{Analytical Method for Residual Oxytetracycline in Livestock and Marine Products}

\author{
Kazuhiro Fujıta*1, Kanako Ito*1, Emiko Arakı*2, Kenji Tanno*2, \\ Mitsunori Murayama*3 and Yukio SaIto*3 \\ (*1 Japan Food Research Laboratories Nagoya Branch: 4-5-13, Osu, Naka-ku, Nagoya 460, \\ Japan; ${ }^{* 2}$ Japan Food Research Laboratories Head Office and Laboratory: 52-1, \\ Motoyoyogi-cho, Shibuya-ku, Tokyo 151, Japan; ${ }^{* 9}$ National Institute \\ of Health Sciences: 1-18-1, Kamiyoga, Setagaya-ku, \\ Tokyo 158, Japan)
}

\begin{abstract}
An analy tical method for residual oxy tetracycline (OTC) in livestock and marine products was evaluated. OTC was extracted from a sample with Mcllvaine buffer ( $\mathrm{pH} 4.0$ ) containing $0.01 \mathrm{~mol} / \mathrm{L}$ EDTA-2 Na. The extract was washed with hexane, followed by a Sep-Pak Plus PS2 cartridge clean-up procedure. OTC was determined by HPLC. The results obtained by HPLC were well correlated with those of a microbioassay method. The average recovery at the tolerance limit levels established by the Food Sanitation Law of Japan was $90.4 \%$ and the determination limits were $0.02 \mathrm{ppm}$ (muscle, seafood, milk), $0.04 \mathrm{ppm}$ (liver, kidney, egg) and $0.002 \mathrm{ppm}$ (fat).
\end{abstract}

(Received May 22, 1996)

Key words: オキシテトラサイクリン oxytetracycline; 微生物学的試検法 microbioassay; 高速 液体クロマトグラフィーHPLC; セップバックフラス PS2カートリッジ Sep-Pak Plus PS2 cartridge

\section{著 言}

平成 7 年 12 月, 食品衙生法が改正され畜水産食品中 のオキシテトラサイクリン(OTC) の残留基準値が設定 されだ12).

従来, 残留抗生物質の分析には, 微生物に対する抗菌 性を利用した平板法による微生物学的試検法が、複合成 分からなる場合が多い抗生物質をトータルに，かつ高感 度に検出することが可能な方法として汎用されてき だ). しかし，その原理は物質の抗菌性を検出する方法

\footnotetext{
*1 (財) 日本食品分析センター名古屋支所： $\mathbf{T} 460$ 名古屋市中 区大須 4-5-13

*2 (財) 日本食品分析センター東京本部: 7151 東京都涉谷区 元代々木町 52-1

*3 国立術生式験所： $=158$ 東京都世田谷区上用潩 1-18-1
}

であり，物質そのものを検出する方法ではないため，検 出された抗菌性物質を特定するには，マイクロパイオ オートグラフィーあろいは HPLCなどにより定性試験 を併用する必要がある。

一方, 近年抗生物質の機器分析における感度の向上 と、OTC が単一成分であることなどから，OTC を含む テトラサイクリン系抗生物質 (TCs) を直接 HPLCによ り定量する方法か数多く辄告されているい 16). しかし， 今回の残留基準值の中には，肉などで $0.1 \mathrm{ppm}$, 脂肪で $0.01 \mathrm{ppm}$ とかなり低濃度に設定されているものあお り,これらの分析法をそのまま遥用することは困難であ ると考えられた。

著者らは，OTCの武速，简便でなおかつ残留基準値 を満足する分析法の礁立を目的とし， Oka らの方法 ${ }^{9)}$ と 


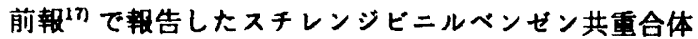
カートリッジの Sep-Pak Plus PS2 による精製を応用 し，HPLCにより定量する方法を検討したところ，良 好な結果が得られたので埌告する。

\section{实䜿方法}

1. 試料

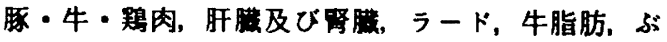
り，えび，牛釈並びに熎卵の市販品を用いた。

\section{2. 試踟菌株}

Bacillus mycoides ATCC 11778 (以下 B. mycoides と略称）を使用した。

\section{3. 試蕌など}

標準品：動物医薬品検查所娭定品の常用標準オキシテ トラサイクリン (OTC) を使用した.

標準溶液：標準品を $1.000 \mu \mathrm{g}$ 力価 $/ \mathrm{mL}$ (ppm) の湌度

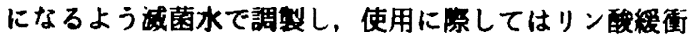
液で逼宜希釈して標準溶雜とした。

その他試薬：和光純菜工業(株)製試薬特級を用いた。

培地：ボリベブトン，細菌用肉エキス，寒天，Antibiotic Medium 8 は，それぞれ日本撆来(株)憋，極東製 莱（株）製，BBL 社㡀，Difco 社㡀を用いた。また，平 板培地の調彆などは，「音水座食品中の残留抗生物筫简 易検查法」(8) の B. mycoides に関する調製法に準じた。 なお，来胞浮遊液の添加量は，培地の $1 / 1000$ 兵とし た.

リン酸縟街液：リン酸一カリウム $13.6 \mathrm{~g}$ を減菌水 $1,000 \mathrm{~mL}$ に溶解し，水酸化カリウム溶液で $\mathrm{pH}$ を 4.5 に調整した。

吸着カラム：Waters 社蔽 Sep-Pak Plus PS2 を用 い,メ夕ノール $10 \mathrm{~mL}$ ，水 $10 \mathrm{~mL}$ 及び飽和 EDTA-2 $\mathrm{Na}$ 溶液 $5 \mathrm{~mL}$ を順に流して調製した。

$1 \mathrm{~mol} / \mathrm{L}$ イミタソール释行液：米田らの方法 ${ }^{10}$ に準 じて調製した。

$0.01 \mathrm{~mol} / \mathrm{L}$ EDTA-2Na 含有マッキルベイン㣪街液 (pH 4.0): 「畜水産食品中の残留抗生物質の分別推定 法」199従って調製した。

ペーバーディスク：Advantec 社幣技肉の抗菌物質検 查用を使用した。

4. 赦

高速液体クロマトグラフ：Waters LC Moduel 1

検出器：(株)島津製作所製 RF-550 蛍光検出器

5. HPLC 渭定条件 ${ }^{10}$

カラム：YMC-PACK ODS-AM AM-312（(株)ワイ エムシィ社製 $6.0 \mathrm{~mm}$ i.d. $\times 150 \mathrm{~mm}$ )

移動相： $1 \mathrm{~mol} / \mathrm{L} イ$ ミタソール級街液ーメタノール $(77: 23)$

流昌: $1.0 \mathrm{~mL} / \mathrm{min}$

测定波長：Ex $380 \mathrm{~nm}, E m 520 \mathrm{~nm}$

カラム温度： $40^{\circ} \mathrm{C}$
注入是: $20 \mu \mathrm{L}$

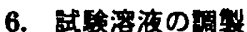

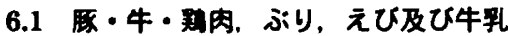

試料 $10 \mathrm{~g}$ を $250 \mathrm{~mL}$ の遠心管にはかりとり，0.01 $\mathrm{mol} / \mathrm{L}$ EDTA-2Na 含有マッキルベイン緩街液 (pH 4.0) $100 \mathrm{~mL}$ を加えてホモジナイスした後，へキサン 100 $\mathrm{mL}$ を加えて 5 分間振とうした。遠心分離 $(3,500 \mathrm{rpm}$ 10 分室温，以下同様）した後，下首をろ紙でろ過して ろ液 $50 \mathrm{~mL}$ を分取し, Sep-Pak Plus PS2 に負荷した. 水 $30 \mathrm{~mL}$ でカラムを洗浄した後、メタノール $10 \mathrm{~mL}$ で OTC を溶出し，溶出液を減圧下 $40^{\circ} \mathrm{C}$ で裟綰乾固し た．残留物をリン酸緩衙液 $2.5 \mathrm{~mL}$ に溶解した後，メン ブランフィルター $(0.45 \mu \mathrm{m})$ でろ過し、武殹溶液とし た.

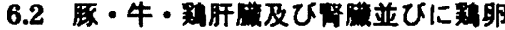

試料 $5 \mathrm{~g}$ を $250 \mathrm{~mL}$ の遣心管にはかりとり，以下 6.1 と同様に行い, 試験溶液とした。

6.3 ラード及ひ牛脂肪

試料 $20 \mathrm{~g}$ を $300 \mathrm{~mL}$ の速心管にはかりとり,へキサ ン $200 \mathrm{~mL}$ を加えてホモジナイスした後，更に 0.01 $\mathrm{mol} / \mathrm{L}$ EDTA-2 Na 含有マッキルベィン楥行波 $(\mathrm{pH}$ 4.0) $40 \mathrm{~mL}$ を加えて再度ホモジナイスした，遠心分墔 した後，下届をろ紙でろ過し，上居に再度 $0.01 \mathrm{~mol} / \mathrm{L}$ EDTA-2Na 含有マッキルベイン楥衙液 (pH 4.0) 20 $\mathrm{mL}$ を加えて同様に操作し，ろ液を合わせて Sep-Pak

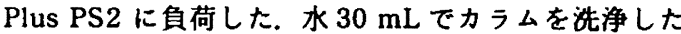
後、メタノール $10 \mathrm{~mL}$ で OTCを溶出し，溶出液を減 压下 $40^{\circ} \mathrm{C}$ で灙縮乾固した。残留物をリン酸綵街液 1 $\mathrm{mL}$ に溶解した後，メンフランフィルター $(0.45 \mu \mathrm{m})$ で ろ過し、試殹溶液とした。

\section{7. 検早億の作成}

7.1 HPLC

$0.04,0.2$ 及び $0.4 \mathrm{ppm}$ の湠度の標準溶液を調製し， その $20 \mu \mathrm{L}$ を高速液体クロマトグラフに注入し，ビー ク高を求めて検正線を作成した。

\section{2 円筒平板法}

平板培地にステンレススチール㱔円筒を置き， 0.05 ， 0.1, 0.2.0.4 及び $0.8 \mathrm{ppm} の$ 湠度に調製した標準溶液を 满たした後， $30^{\circ} \mathrm{C} て ゙ 16 〜 18$ 時間培養して円筒周辺に 生じた阻止円直径から検五線を作成した。

\section{結果及ひ考察}

1. HPLC 条件の検討

Oka らの方法" ${ }^{9}$ に藻じた UV 検出法と米田らの方法 ${ }^{10}$ に染じた蛍光検出法について検出感度の比较を行った，

その結果、ほぼ同じ保持時間における $0.04 \mathrm{ppm}$ 湌度 の標準溶液のピーク高を比较した場合, 虽光検出法の $\mathrm{S} / \mathrm{N}$ 比は約 20, UV 検出法は 4 5 であり, 蛍光検出 法がより低湌度の OTC の検出法として有用であると考 えられた。 


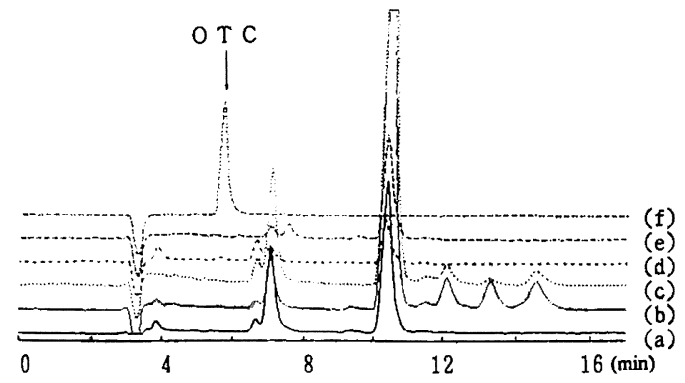

Fig. 1. HPLC chromatograms of sample extracts and standard solution

(a): cattle muscle; (b): cattle liver; (c): cattle kidney; (d): yellowtail; (e): egg; (f): $4 \mathrm{ng}$ of OTC

Table 1. Efficiency of Extraction Using McIlvaine Buffer ( $\mathrm{pH} 4.0$ ) Containing 0.01 $\mathrm{mol} / \mathrm{L}$ EDTA-2Na

\begin{tabular}{lccc}
\hline \hline \multicolumn{1}{c}{ Sample } & $\begin{array}{c}\text { Spiked } \\
(\mathrm{ppm})\end{array}$ & $\begin{array}{c}\text { Volumes } \\
(\mathrm{mL})\end{array}$ & $\begin{array}{c}\text { Recovery } \\
(\%)\end{array}$ \\
\hline Swine muscle & 0.1 & 100 & 89.5 \\
& & 40,20 & 84.3 \\
Swine liver & 0.3 & 100 & 89.5 \\
& & 40,20 & 86.2 \\
Swine kidney & 0.6 & 100 & 93.0 \\
& & 40,20 & 91.5 \\
Cattle fat & 0.01 & 100 & 70.0 \\
& & 40,20 & 76.3 \\
\hline
\end{tabular}

Fig. 1 に, 虽光検出法による牛肉, 牛肝滕, 牛腎䑏, ぶり及び䁿卵のクロマトグラムを示した．いずれにおい ても，UV 検出法の場合のように，OTCのピークが， 早い保持時間の夾雑ピークのショルターーに重なることも なく，良好な分離を示した。

\section{2. 試験溶液眮䈨法の検讨}

畜水産食品中からのOTCの抽出には, マッキルべ

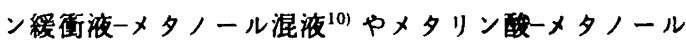
混液 ${ }^{16)}$ を用いている報告があるが，その場合，後の力 ラム操作のためにメタノールの除去を必要とする.

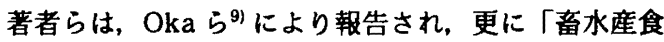
品中の残留抗生物質の分別推定法」で用いられている $0.01 \mathrm{~mol} / \mathrm{L}$ EDTA-2 Na 含有マッキルベイン緩街液 (pH 4.0)を抽出液とし, 前報17) で報告した Sep-Pak

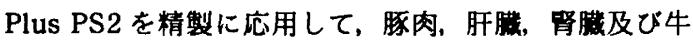
脂肪を用いて基準値レベルの添加濃度における抽出回数 の検討を行った. その結果, Table 1 に示したように, 豚肉, 肝脿, 督埛については抽出回数による差はなく， 1 回抽出で十分であると判断された。一方, 牛脂肪は, 添加涱度が低いためか, 1 回抽出では不十分であり, 2 回抽出が必要であると考えられた。
Table 2. Recoveries of OTC by the Developed Method

\begin{tabular}{llrl}
\hline \hline \multicolumn{1}{c}{ Sample } & $\begin{array}{c}\text { Spiked } \\
\text { (ppm) }\end{array}$ & $\begin{array}{c}\text { Recovery*1 } \\
(\%)\end{array}$ & $\begin{array}{c}\text { RSD } \\
(\%)\end{array}$ \\
\hline Cattle muscle & 0.1 & 92.2 & 1.6 \\
& 0.02 & 84.1 & 8.1 \\
Cattle liver & 0.3 & 89.8 & 1.0 \\
& 0.04 & 102.6 & 9.9 \\
Cattle kidney & 0.6 & 94.6 & 2.3 \\
& 0.04 & 96.3 & 3.3 \\
Swine muscle & 0.1 & 89.5 & 0.9 \\
Swine liver & 0.3 & 89.5 & 3.2 \\
Swine kidney & 0.6 & 93.0 & 1.0 \\
Chicken muscle & 0.1 & 87.5 & 0.6 \\
Chicken liver & 0.3 & 96.3 & 5.9 \\
Chicken kidney & 0.6 & 92.9 & 3.2 \\
Yellowtail & 0.1 & 88.9 & 3.1 \\
& 0.02 & 81.3 & 7.3 \\
Prawn & 0.1 & 87.3 & 6.4 \\
Egg & 0.2 & 93.0 & 2.7 \\
& 0.04 & 100.8 & 4.3 \\
Milk & 0.1 & 85.5 & 0.5 \\
& 0.02 & 78.4 & 2.3 \\
Lard & 0.01 & 75.5 & 5.6 \\
& 0.002 & 88.7 & 5.2 \\
Cattle fat & 0.01 & 76.3 & 3.0 \\
& 0.002 & 86.1 & 2.2 \\
\hline
\end{tabular}

The average of 3 replications

また, Oka らの叝告")では，抽出液をろ過後，直接 $\mathrm{C}_{18}$ 系カートリッジにより処理をしているが, 豚肉, 肝 脿及び㛭腊について同様に行ったところ，豚肉のろ液に 浮遊物が生じ, Sep-Pak Plus PS2 カートリッジの処理 で目詰まりを起こした，そこで，抽出液をへキサンによ り洗浄したところ, 浮遊物は除去され，カートリッシ処 理の操作性も向上した.

\section{3. 添加回収試駼}

Table 2 に示した各組織について添加回収試験を実施 した，その結果, ラード及び牛脂肪の残留基準値レベル と牛乳の定量下限レベルの平均回収率が $70 \%$ 台であっ たが，それ以外は $80 \%$ 以上，相対標準偏差はいずれす 10\%以内と良好な結果が得られた。 また, 調製した試 験溶液は $5^{\circ} \mathrm{C}$ において 3 日間安定であった。

なお，本法における定量下限は，肉, 魚介類, 牛乳の

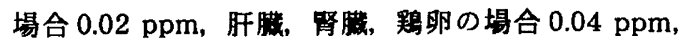
脂肪の場合 $0.002 \mathrm{ppm}$ であった.

\section{HPLC と円筒平板法の相閶性}

一般に抗生物望である OTC の残留分析には微生物学 的試験法が公定法音として採用されている.したがっ て, HPLCによる本法之, 微生物学的式験法との相関 性を確認する必要性がある。にここで，豚肉，肝嘰及び焣 


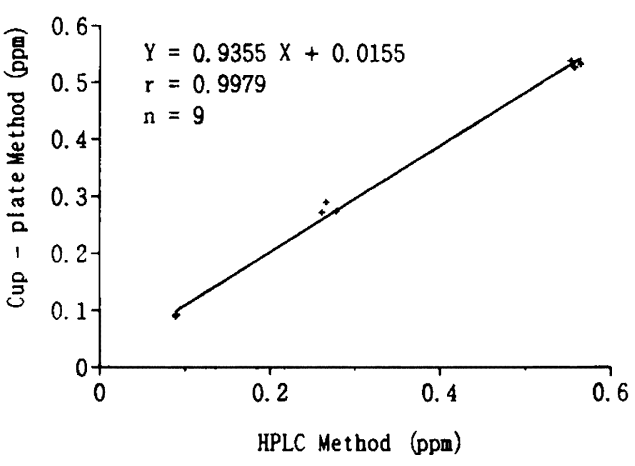

Fig. 2. Correlation between HPLC and Cupplate method for OTC in swine muscle, liver and kidney

䑏を用いて残留基準値レベルの添加浸度において, HPLC と円筒平板法の相関性を調へた。.

その結果, Fig. 2 に示したように, 両法の定典値の 相関性は高く，相関係数は 0.9979 であった。

更に、円筒平板法よりも簡便なペーパーディスク法に よっても残留基準値レベルの検出が可能であることを確 認しており，多検体を効率良く処理するための简易スク リーニング法として, 微生物学的試挽法は有用であると 考えられた。

\section{5. 市販食品の分析}

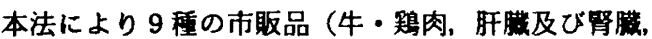
ぶり，えび並びに鷄卵）計 49 試料について分析を行っ たが，いずれの試料からも OTCは検出されず，OTC のピークの位置に夾嚾物は見られなかった。

\section{诘詥}

OTC の司速，簡便な残留分析法の確立を目的として， HPLCにより定量する方法を検討し, 以下の結論を得 た.

1. UV 検出法と蛍光検出法を比較した結果, 蛍光検 出法が有効であった.

2. 抽出液として $0.01 \mathrm{~mol} / \mathrm{L}$ EDTA-2Na 含有マッ キルベイン縟街没 (pH 4.0) を用い，精製カラムとして Sep-Pak Plus PS2 を用いたところ, 迅速, 简便な方法 汃確立され, 残留基準値レベルの添加回収試耠の平均回 収率は, $90.4 \%$ であった。 また, 定量下限は, 肉, 魚

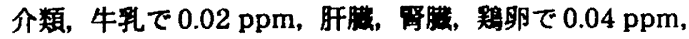
脂肪で $0.002 \mathrm{ppm}$ であった.

3. 本法之微生物学的試䖍法（円筒平板法）の定且値 の相関性は良好であった。

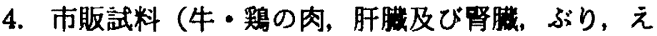
び並びに鶏卵）の計 49 試料について分析を行ったが, OTC は検出されなかった。

付記

本研究は, 平成 6 年度医生科学研究貫（食品衙生調 查研究事業）㭪助金で行ったものである。

文塥

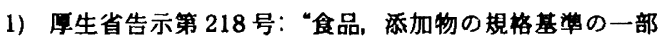
改正”平成 7 年 12 月 26 日 (1995).

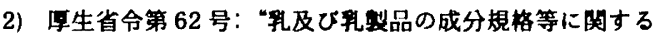
省令の一部改正”平成 7 年 12 月 26 日 (1995).

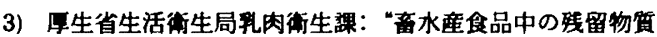
娭査法" (1990)

4) Knox, H. J., Jurand, J.: J. Chromatogr. 186. 763 782 (1979).

5) Eksborg, S., Ekqvist, B.: ibid. 209, 161 173 (1981).

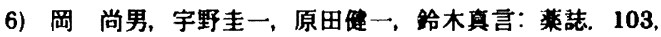
531 537 (1983).

7) Oka, H., Uno, K., Harada, K., Yasaka, K., Suzuki, M.: J. Chromatogr. 298, 435 443 (1984).

8）寺田久屋, 麻野間正晴, 坂部美雄：術生化学 30，138～ 143 (1984).

9) Oka, H., Matsumoto,H., Uno, K.: J. Chromatogr. 325, 265 274 (1985).

10）米田 豊，古城典子，安藤良吉：食術范， 30，42 47 (1989).

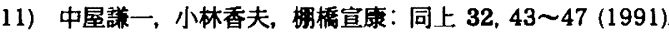

12) Fletouris, J. D., Psomas, E. J., Botsoglou, A. N.: J. Agric. Food Chem, 38, 1,913 1,917 (1990).

13) Walsh, R. J., Walker, V. L., Webber, J. J.: J. Chromatogr. 596, 211 216 (1992).

14) Iwaki, K., Okumura, N., Yamazaki, M.: ibid. 623. $153 \sim 158$ (1992).

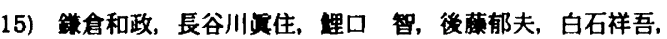
平田震志，山名萃善，外海泰秀：食術誌。35, 310 314 (1994).

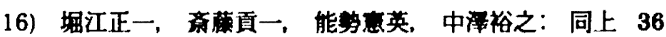
293 297 (1995).

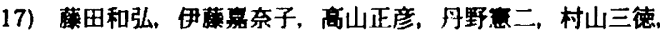
斎藤行生：同上 37, 222 225 (1996).

18）厚生省生活街生局長通知：“平成 6 年度畜水産食品中の 残留有害物窗モニタリング梌直の実施について 別添 2

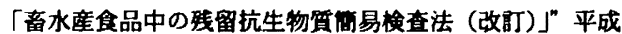
6 年 7 月 1 日, 街乳第 108 号 (1994).

19）同上，別添 3 「畜水産食品中の残留抗生物筫の分別推定 法（改新)」平成 6 年 7 月 1 日, 術乳第 108 号 (1994). 